\title{
Effects of sugarcane juice addition on the population dynamics of Escherichia coli and the presence of Shiga-toxigenic $E$. coli during the anaerobic codigestion of dairy cattle manure
}

\author{
Paula Maria Pilotto Branco ${ }^{*}$ Aline Fernandes ${ }^{2}$ Max Ternero Cangani ${ }^{3}$ \\ Andressa de Souza-Pollo ${ }^{4}$ Jorge de Lucas Júnior $^{5}$ Luiz Augusto do Amaral ${ }^{1}$
}

${ }^{1}$ Departamento de Medicina Veterinária e Reprodução Animal, Faculdade de Ciências Agrárias e Veterinárias (FCAV), Universidade Estadual Paulista (UNESP), 14884-900, Jaboticabal, SP, Brasil. E-mail: paulapilotto@ hotmail.com. "Corresponding author.

${ }^{2}$ Faculdade de Ciências Agrárias, Universidade Estadual Paulista, Botucatu, São Paulo, Brasil

${ }^{3}$ Instituto Federal Catarinense (IFC), Camboriú, SC, Brasil.

${ }^{4}$ Departamento de Medicina Veterinária e Reprodução Animal, Laboratório de Epidemiologia Molecular, Faculdade de Ciências Agrárias e Veterinárias, Universidade Estadual Paulista, Jaboticabal, SP, Brasil.

${ }_{5}^{5}$ Departamento de Engenharia Rural, Faculdade de Ciências Agrárias e Veterinárias, Universidade Estadual Paulista, Jaboticabal, SP, Brasil.

ABSTRACT: The objective of this study was to evaluate the effects of the addition of sugarcane juice on the population dynamics of Escherichia coli and the presence of Shiga-toxigenic E. coli (STEC) during the anaerobic codigestion of dairy cattle manure. For the overall analyses at the end of a hydraulic retention time of 90 days, ten two-liter batch-type biodigesters were divided into two treatment groups: biodigester containing manure and water (MW) and the biodigester containing manure, water and sugarcane juice (MSC). For monitoring the population dynamics and presence of microorganisms, $\mathrm{pH}$, and volatile acidity, tests were carried out every ten days, on 36 smaller-scale batch biodigesters made of one-liter plastic bottles (18 for each treatment). The reductions in E. coli population over time were significant in the MW (60 days) and MSC (20 days) biodigesters. Inactivation of STEC occurred in a shorter period (40 days in MW and $<10$ days in MSC). Significant differences were obtained between the two treatments, with the pH values being lower, the concentrations of volatile acids (VA) being higher, and the inactivation of E. coli and STEC being faster in the biodigester with sugarcane juice added. The amount of sugarcane juice applied (7\%) suggests its suitability for the sanitization of dairy cattle manure for use as a biofertilizer, given the high reduction in the E. coli population and inactivation of STEC.

Key words: biodigestion anaerobic, environmental sustainability, pathogenic microorganisms, manure treatment.

Efeito da adição de caldo de cana-de-açúcar na dinâmica da população de Escherichia coli e presença de $E$. coli shigatoxigênicas durante a codigestão anaeróbia de dejetos bovinos leiteiros

RESUMO: O estudo teve como objetivo avaliar o efeito da adição de caldo de cana-de-açúcar sobre a dinâmica da população de Escherichia coli e presença de E. coli shigatogixênicas (STEC) no processo de codigestão anaeróbia de dejetos de bovinos leiteiros. Foram utilizados dez biodigestores bateladas divididos em dois tratamentos, dejeto sem caldo de cana-de-açúcar (DSC) e dejeto com caldo (DCC), com tempo de retenção hidráulica (TRH) de 90 dias. Para o monitoramento periódico da dinâmica da população E. coli e presença de E. coli shigatoxigenicas, do pH e da acidez volátil, realizados a cada dez dias, foram abastecidos mais 36 biodigestores bateladas, construídos de garrafas de material plástico de um litro, sendo 18 unidades para cada tratamento. A redução das populações de E. coli no decorrer do tempo foi significativa no DSC (60 dias) e no DCC (20 dias). A inativação de E. coli shigatoxigênicas ocorreu em um periodo mais curto, 40 dias no DSC e menos de 10 dias no DCC. Foram obtidas diferenças significativas entre os tratamentos para os valores de pH, que foram menores, $e$ as concentrações de ácidos voláteis, que foram maiores, com adição de caldo e contribuíram para a inativação mais rápida da E. coli e STEC. A dose de caldo de cana-de-açúcar utilizada (7\%) sugere a adequada sanitização do dejeto bovino leiteiro, tendo em vista a alta redução na população de E. coli e a inativação de STEC.

Palavras-chave: biodigestão anaróbia, micro-organismos patogênicos, sustentabilidade ambiental, tratamento de dejetos.

\section{INTRODUCTION}

The deposition of natural manure in the soil can transfer pathogenic microorganisms to the food chain (NICHOLSON et al., 2005) and contaminate water resources (AVERY et al., 2004), since cattle manure may contain more than 150 pathogens that could endanger human, animal, and environmental health (GERBA; SMITH, 2005).

Escherichia coli, which is ubiquitous in the environment, is considered a global indicator of fecal pollution. Some strains have acquired genes that make them capable of causing intestinal or extraintestinal diseases; for example, Shiga-toxigenic 
E. coli (STEC) strains, which produce at least one type of shigatoxin ( $s x_{1}$ orst $x_{2}$ ) (KAPER et al., 2004; GYLES; FAIRBROTHER, 2010). Ruminants, especially cattle, are important reservoirs of these microorganisms. The occurrence of STEC in Brazil was reviewed by Caldorin et al. (2013), who observed a variation of $5.2-82 \%$ in feces from dairy cattle.

In addition to the environmental benefits caused by reducing the emission of greenhouse gases (ORZI et al., 2010), the use of anaerobic biodigestion for the treatment of animal manure has been a great ally in reducing the impact generated by pathogenic microorganisms (SAHLSTRÖM et al., 2008).

With the objectives of maximizing the production of biogas (ORRICO et al., 2016; XAVIER et al., 2016) and also decreasing the retention time of substrates (ORRICO et al., 2016), some authors have investigated the codigestion and the association of manures with other residues, such as sugarcane juice (XAVIER et al., 2016).

Conversely, sugarcane juice provides a more acidic medium, which may favor the inactivation of bacteria (SUNG; LIU, 2003). According to Sung and Liu (2003), Sahlström (2003), and Kunte et al. (2004), high concentrations of VA combined with an acidic $\mathrm{pH}$ are responsible for the reduction of pathogens in the mesophilic biodigestion process.

The objective of the study was to evaluate the effects of the addition of sugarcane juice on the dynamics of Escherichia coli population and the presence of STEC strains in dairy cow manure being processed by anaerobic codigestion.

\section{MATERIALS AND METHODS}

For this study, batch biodigesters with an approximate capacity for $2 \mathrm{~L}$ of fermentation substrate were used, with a hydraulic retention time (HRT) of 90 days. The ten biodigesters were divided into two treatments of five replicates each, designated manure without sugarcane juice (MW) and manure with sugarcane juice (MSC). Samples were taken from both manures at the end of the HRT $\left(\mathrm{T}_{90}\right)$ to perform all analyses.

To follow the dynamics of the E. coli population, the presence of STEC, and the $\mathrm{pH}$ and volatile acidity from $\mathrm{T}_{10}$ to $\mathrm{T}_{80}, 36$ batch biodigesters were produced on a smaller scale, using plastic bottles with a volume of 1L. Thus, at every ten days, two new bottles were used for the analyses, totaling 18 batch units for each treatment.

The substrates were prepared to contain $6 \%$ of total solids (TS) and 7\% of sugarcane juice.
The MW substrate was composed of $32.4 \mathrm{~L}$ of water and $16.2 \mathrm{Kg}$ of dairy cattle manure, having $5.18 \%$ of TS and $4.22 \%$ of volatile solids (VS) and a $\mathrm{pH}$ value of 6.21 . The MSC substrate was composed of $28.998 \mathrm{~L}$ of water, $16.2 \mathrm{Kg}$ of dairy cattle manure, and $3.402 \mathrm{~L}$ of sugarcane juice, having $5.36 \%$ of TS and $4.26 \%$ of $\mathrm{VS}$ and a $\mathrm{pH}$ of 6.07 .

For the microbiological analysis, E. coli counts were determined by the spread plate method (samples diluted from $10^{-1}$ to $10^{-6}$ ) on Violet Red Bile Agar containing 4-methylumbelliferyl- $\beta$-Dglucuronide, with incubation at $35^{\circ} \mathrm{C}$ for 24 hours. Red colonies with fluorescence under ultraviolet light were considered positive for E. coli (APHA, 2001).

According to the criterion described by Sutton (2011), if no colony was detected on the plate, then the count was considered to be lower than the detection limit of the technique and the respective HRT was considered as the survival time of E. coli. In the present study, the limit of detection was $10^{2} \mathrm{CFU} \mathrm{mL} \mathrm{m}^{-1}$.

The identification of STEC was performed in duplicate for each sample. The presence of $s t x_{1}$, $\mathrm{s} t x_{2}$, and eae genes was determined by the polymerase chain reaction (PCR), using specific oligonucleotide primers (CHINA et al., 1996).

DNA extraction from total bacterial cultures in Brain Heart Infusion broth was performed by thermal lysis, by heating the cell suspension to $100^{\circ} \mathrm{C}$. The amplification reaction mixture for each gene was composed of $1 \times$ buffer $(20 \mathrm{mM}$ Tris-HCl, $\mathrm{pH}$ 8.4 , and $50 \mathrm{mM} \mathrm{KCl}$ ), $2 \mathrm{mM} \mathrm{MgCl}_{2}, 0,2 \mathrm{mM}$ dNTPs, $1 \mathrm{U}$ of Taq DNA polymerase, 5 pmol of each primer, $2 \mu \mathrm{L}$ of genomic DNA, and sterile pure water to make up a $20 \mu \mathrm{L}$ volume. The reactions were carried out in a thermocycler, programmed as follows: $95^{\circ} \mathrm{C}$ for $3 \mathrm{~min}$; 35 cycles of $94^{\circ} \mathrm{C}$ for $30 \mathrm{~s}, 55^{\circ} \mathrm{C}$ for $30 \mathrm{~s}$, and $72^{\circ} \mathrm{C}$ for $30 \mathrm{~s}$; and a final cycle of $72^{\circ} \mathrm{C}$ for $10 \mathrm{~min}$. The DNA of E. coli strain EcL 6611 was used as a positive control, whereas the negative control was a reagent mix tube without DNA. The PCR products were visualized by $1 \%$ agarose gel electrophoresis in $1 \times$ TBE buffer (89mM Tris, 89mMboric acid, and 2.5mM EDTA).

The $\mathrm{pH}$ readings of the affluents and effluents of the biodigestion systems were determined according to the method described by the APHA (2012). Volatile acid determination was performed by titration, as described by Dilallo and Albertson (1961).

Before statistical analysis, the data were analyzed by the Shapiro-Wilks normality test. If normal, a parametric test was used, and if not, a nonparametric test was used. The variation of the $E$. coli population over time was compared by linear regression analysis. For comparison of the $\mathrm{pH}$ values 
in the MW and MSC treatments, the Wilcoxon test was used. For the concentrations of volatile acids, the paired $t$-test for comparison of averages was performed (SIQUEIRA; TIBÚRCIO, 2011).

\section{RESULTS AND DISCUSSION}

The survival time of $E$. coli in the sugarcane juice treated biodigester was 20 days. In the MW biodigester, no $E$. coli colonies were observed at 60 , 70 , and 80 days. However, this microorganism was detected again within 90 days of the biodigestion process although in a smaller number than that at the start of the treatment (Table 1).

The absence of $E$. coli in the treated biodigesters may have been due to the limit of detection of the technique, or to stress caused to the microorganism during biodigestion that led to it being non-cultivable. Under certain conditions, the microorganism could recover and be detected again (HIGGINS et al., 2007).

The decrease in the E. coli population over time was significant for both MW $(\mathrm{P}<0.01)$ and MSC $(\mathrm{P}<0.05)$ treatments (Table 1$)$. It is worth mentioning that the $3 \log$ reduction obtained at 60 and 20 days of HRT in the MW and MSC biodigesters, respectively (Table 1), is important in order to minimize the risk of dissemination of soil pathogens if the effluent is used as a biofertilizer (HUTCHISON et al., 2004).

The reduction of $E$. coli populations in this study was greater than that reported by Lang and Smith (2008), who obtained a 1-2 log decrease from the anaerobic mesophilic digestion of a sewage sample. Pandey and Soupir (2011) and Manyi-Loh et al. (2014) obtained E. coli population decreases of $1 \log$ after 7-8 days and 1-2 log after 62 days, respectively, in the anaerobic mesophilic biodigestion of dairy cattle feces.

The bacterial colonies from the MW and MSC affluent showed amplification of stx $x_{2}$ and eae genes. In the MW biodigester, STEC was detected in the effluent for up to 40 days, but was only detected in the affluent of the MSC system. In both types of biodigesters, colonies from the STEC group were not detected after 90 days (Figure 1).

In the MSC biodigester, the time taken to inactivate STEC was shorter than that taken to reduce the $E$. coli population (Table 1), indicating that commensal $E$. coli remained active for a longer period. Gonçalves and Marin (2007) also verified the longer survival of $E$. coli (120 days) than of STEC (4-30 days) in the anaerobic treatment of dairy cattle manure.

Kudva et al. (1998) showed that, at $23^{\circ} \mathrm{C}$, a negative toxin strain of $E$. coli $\mathrm{O} 157: \mathrm{H} 7$ survived longer than the positive toxin strain. Van Elsas et al. (2011) stated that this difference in survival time may be related to the fact that pathogenic $E$. coli strains require more energy to produce toxins, which compromises their survival capacity.

Whereas Andrade et al. (2012) have shown a higher expression of gene $s t x_{1}$ than of $s t x_{2}$ in dairy calves in Minas Gerais State, the same was not verified by Carvalho et al. (2012), Vicente et al. (2010), and Irino et al. (2005), who observed the opposite gene expression trend in dairy cattle manure. These latter

Table 1 - Dynamics the E. coli population (CFU), hydrogenation potential values (pH) e volatile acids (VA), during the 90-day biodigestion period.

\begin{tabular}{|c|c|c|c|c|c|c|}
\hline \multirow{2}{*}{ HRT } & \multicolumn{3}{|c|}{ MW } & \multicolumn{3}{|c|}{ MSC } \\
\hline & $\mathrm{CFU} \mathrm{mL} \mathrm{L}^{-1}$ & $\mathrm{pH}$ & VA $\mathrm{mg} \mathrm{L}^{-1}$ & $\mathrm{CFU} \mathrm{mL} \mathrm{m}^{-1}$ & $\mathrm{pH}$ & VA mg L ${ }^{-1}$ \\
\hline $\mathrm{T} 0$ & $6.50 \mathrm{E}+05$ & 6.21 & 3060 & $8.80 \mathrm{E}+05$ & 6.07 & 2712 \\
\hline $\mathrm{T} 10$ & $1.45 \mathrm{E}+04$ & 5.35 & 4416 & $2.02 \mathrm{E}+04$ & 4.68 & 5328 \\
\hline $\mathrm{T} 20$ & $3.35 \mathrm{E}+03$ & 5.86 & 2232 & $<\mathrm{LOD}$ & 4.60 & 5052 \\
\hline T30 & $1.38 \mathrm{E}+04$ & 6.82 & 2214 & $<$ LOD & 4.59 & 6180 \\
\hline $\mathrm{T} 40$ & $1.17 \mathrm{E}+04$ & 6.84 & 2520 & $<$ LOD & 4.69 & 5340 \\
\hline $\mathrm{T} 50$ & $1.74 \mathrm{E}+04$ & 6.68 & 1908 & $<$ LOD & 4.85 & 6000 \\
\hline T60 & $<$ LOD $^{*}$ & 6.91 & 1710 & $<$ LOD & 4.91 & 5652 \\
\hline $\mathrm{T} 70$ & $<$ LOD & 6.77 & 1200 & $<\mathrm{LOD}$ & 4.65 & 6972 \\
\hline T80 & $<\mathrm{LOD}$ & 6.90 & 1674 & $<\mathrm{LOD}$ & 4.80 & 4404 \\
\hline T90 & $4.20 \mathrm{E}+02$ & 6.68 & 2406 & $<$ LOD & 4.64 & 8424 \\
\hline Average & - & 6.50 & 2334 & - & 4.85 & 5606 \\
\hline
\end{tabular}

*Limit of detection. HRT: hydraulic retention time. MW: manure and water. MSC: water and sugercane juice. CFU: colony forming unit. $\mathrm{pH}$ : hydrogenation potential values. VA: volatile acids. 


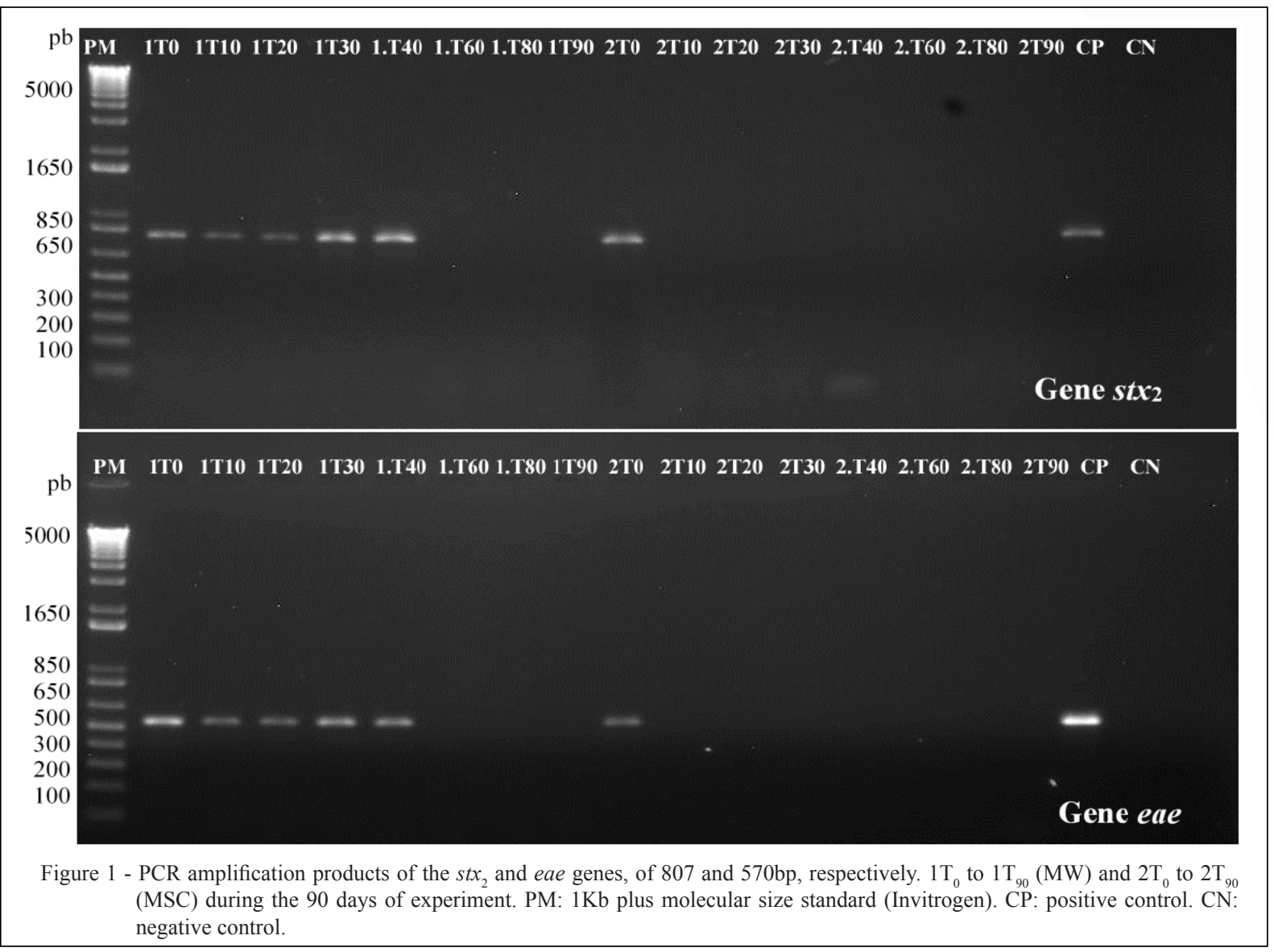

studies corroborate the results of our present study, where the presence of gene stx $x_{1}$ was not detected in both biodigester treatments.

STEC survive for considerable periods in animal feces and can thus contaminate the soil. Fukushima et al. (1999) and Duffy (2003) have verified the long survival periods of serotypes O157:H7 (49-126 days) and O26:H11 (112 days) and serogroup O111 (70 days). By reaching the soil, these microorganisms can be viable for a period sufficient to contaminate food and water. Mukherjee et al. (2006) observed the survival of this microorganism for more than 92 days in garden soil, and Islam et al. (2004) verified a viability of 154-217 days in cultivated soils, both contaminated by animal feces.

Thus, anaerobic digestion represents an important tool for sanitizing effluents, as it is an ecological strategy, can significantly reduce pathogenic $E$. coli, is not expensive, and is easily applicable in rural areas (FREMAUX et al., 2008).

With regard to the VA and $\mathrm{pH}$, significant differences were obtained $(\mathrm{P}<0.01$ and $\mathrm{P}<0.05$, respectively) between the MW and MSC treatments (Table 1), with the changes in the sugarcane juiceadded process contributing to the rapid inactivation of $E$. coli. The $\mathrm{pH}$ variation in the effluents during the biodigestion process ranged from 5.35 to 6.91 and from 4.59 to 6.07 in the MW and MSC treatments, respectively (Table 1 and Figure 2).

For the MW treatment, the lowest $\mathrm{pH}$ values were obtained for up to 20 days, increasing over time, indicating that although many acids were formed, they were consumed throughout the process. All the $\mathrm{pH}$ values obtained were within the ideal range, which varies from 6.6 to 7.4 for anaerobic digestion, as described by Chernicharo (1997). However, in the MSC system, the values varied below this range, from 4.59 to 6.07 (Table 1 and Figure 2).

The volatile acidity of the effluents from the MW batch biodigesters ranged from 1200 to $4416 \mathrm{mg} \cdot \mathrm{L}^{-}$ ${ }^{1}$. For the MSC systems, an increase in the acidity of the medium was also observed, varying between 2712 and $8424 \mathrm{mg} \cdot \mathrm{L}^{-1}$ (Table 1 and Figure 3). After 10 days of operation, it was evident that the high acidity of the 

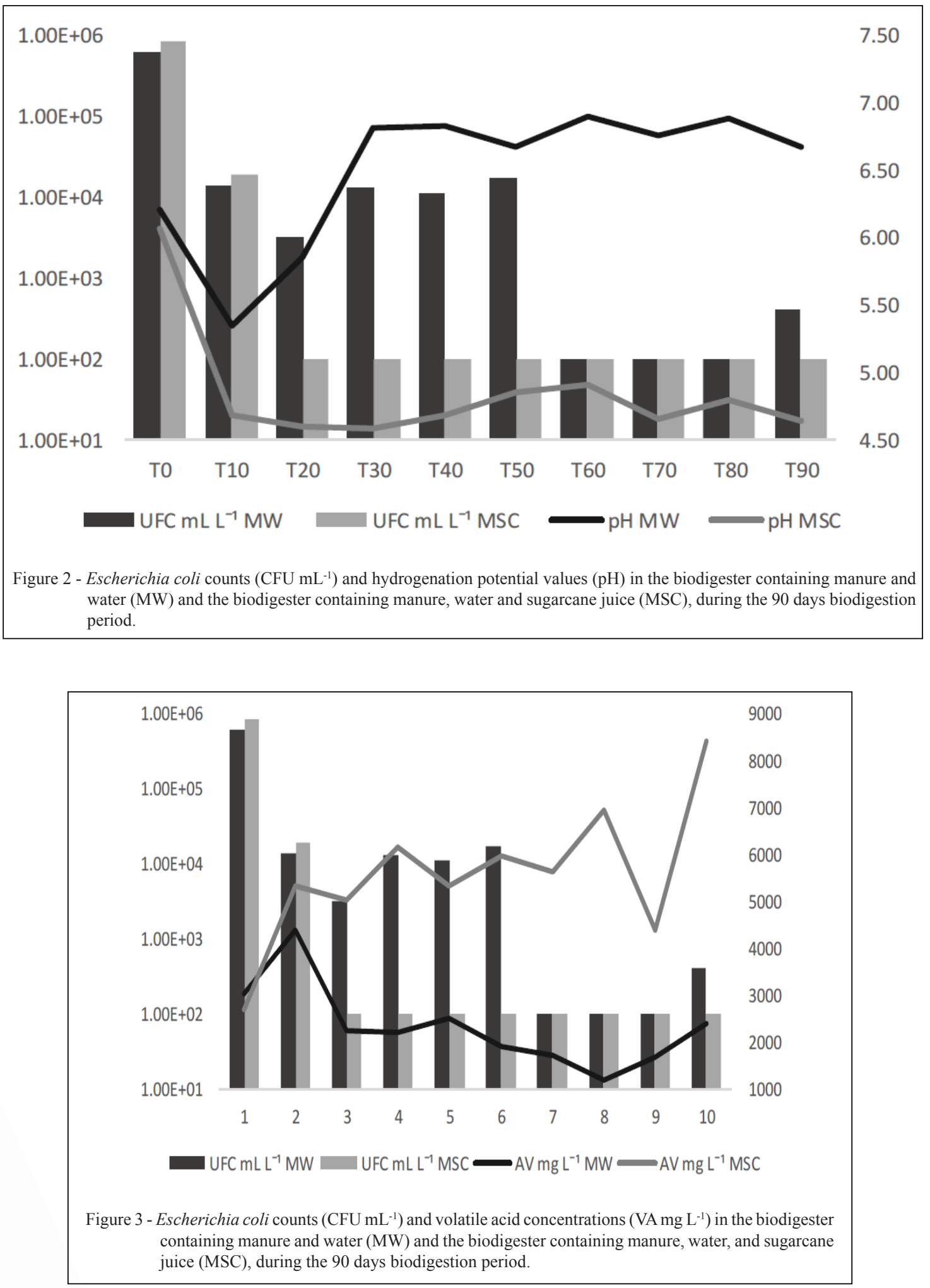

Ciência Rural, v.48, n.3, 2018. 
medium in the biodigesters containing sugarcane juice had a direct influence on the inactivation of the bacteria.

Abdul and Lloyd (1985) suggested that volatile acidity is an important factor for reducing pathogenic microorganisms during the process of anaerobic biodigestion. According to Henry et al. (1983), the toxicity of VA toward bacteria varies with the medium $\mathrm{pH}$, where that toward Salmonella typhimurium was much greater at $\mathrm{pH} 4.0$ than at $\mathrm{pH} 5.0$ or higher.

Although, sugarcane juice can be used as a substrate in biodigesters with the main objective of increasing $\mathrm{CH}_{4}$ production, it could in practice lead to the rapid formation of acids and an abrupt reduction of $\mathrm{pH}$ due to the supply of readily soluble carbohydrates (XAVIER et al., 2016) creating toxic conditions for different microorganisms (SAHLSTRÖM, 2003; KUNTE et al., 2004).

Thus, the acidity of the medium is an important factor in the reduction of pathogenic microorganisms in substrates undergoing biodigestion. According to Strauch (1986), 90\% of the reduction in Salmonella spp. was due to the decrease in the medium $\mathrm{pH}$, with the drop being influenced by the acids produced by the microorganisms involved in the biodigestion process, which have a toxic effect on Salmonella. The author also pointed out that ammonia was not responsible for the decrease in the bacteria, because it is formed in medium with a $\mathrm{pH}$ between 8.0 and 9.0.

Thus, it is clear that the addition of sugarcane juice can positively influence the sanitation of excreta. In addition, this codigestion allows the restricted use of the biofertilizer in less time and with less risk to public, animal, and environmental health, when compared with the treatment without addition of the sugarcane juice.

It is worth emphasizing the need for this by-product (i.e., the biofertilizer) to meet the criteria established (since 2006) for its production, import, and marketing according to Normative Instruction SDA No.27, which limits the maximum number of thermotolerant coliforms to $1000 \mathrm{MPN} \cdot \mathrm{g}^{-1}$ of $\mathrm{DM}$. The results of the MSC treatment were within the established criteria, which was not observed for the MW treatment.

\section{CONCLUSION}

The codigestion of dairy cattle manure with $7 \%$ of sugarcane juice produced very interesting results, suggesting the successful sanitization of the by-product in accordance with the established criteria for biofertilizers. Thus, the reduction of the E. coli population and inactivation of STEC ( $s t x_{2}$ and eae) make the product feasible for use in the form of a fertilizer.

\section{ACKNOWLEDGEMENTS}

The authors are grateful for the scholarship granted by the Coordenação de Aperfeiçoamento de Pessoal de Nível Superior (CAPES). We also acknowledge the Graduate Program in Veterinary Medicine, FCAV/UNESP, Jaboticabal.

\section{REFERENCES}

ABDUL, P., LLOYD, D. Pathogen survival during anaerobic digestion: Fatty acids inhibit anaerobic growth of Escherichia coli. Biotechnology Letters, v. 7, n. 2, p. 125-128, Fev. 1985. Available from: < https://link.springer.com/article/10.1007\%2FBF01026683 ?LI=true $>$. Accessed: Mai. 05, 2017. doi: 10.1007/BF01026683.

APHA - AMERICAN PUBLIC HEALTH ASSOCIATION. 2012. Standard methods for the examination of water and wastewater. 22nd ed. APHA. Washington.

APHA - AMERICAN PUBLIC HEALTH ASSOCIATION. 2001. Committee on Microbiological for Foods. Compendium of methods for the microbiological examination of foods. 4 ed. APHA. Washington.

ANDRADE, G. I. et al. Identification of virulence factors by multiplex PCR in Escherichia coli isolated from calves in Minas Gerais, Brazil. Tropical Animal Health and Production, v. 44, n. 7, p. 1783-1790, Out. 2012. Available from: <https://link.springer.com/article/10.1007/s11250-0120139-8>. Accessed: Mai. 05, 2017. doi: 10.1007/s11250-0120139-8.

AVERY, S. M. et al. Fate of Escherichia coli originating from livestock feces deposited directly onto pasture. Letters in Applied Microbiology, v. 38, n. 5, p. 355-359, 2004. Available from: $\quad<$ http://onlinelibrary.wiley.com/doi/10.1111/j.1472765X.2004.01501.x/abstract>. Accessed: Mai. 19, 2017. doi: 10.1111/j.1472-765X.2004.01501.X

CARVALHO, A. F. et al. Molecular and phenotypic characterization of shiga toxin producing Escherichia coli (STEC) non-O157 strains from bovine feces and carcass. Arquivo Brasileiro de Medicina Veterinária e Zootecnia, Belo Horizonte, v. 64, n. 4, p. 881-886, Ago. 2012. Available from: <http://www.scielo.br/scielo. php?script=sci_abstract\&pid=S0102-09352012000400014\&lng=en \&nrm=iso\&tlng=pt $>$. Accessed: Mai. 05, 2017. doi: 10.1590/S010209352012000400014.

CALDORIN, M. et al. Occurrence of Shiga toxin-producing Escherichia coli (STEC) in Brazil and its public health importance. Boletim Epidemiológico Paulista, São Paulo, v. 10, n. 110, p. 4-20, Fev. 2013.

CHERNICHARO, C. A. L. Reatores anaeróbios: princípios do tratamento biológico de águas residuárias. Belo Horizonte: Polytécnica LTDA, 246p., 1997.

CHINA, B. et al. Typing of bovine attaching and effacing Escherichia coli by multiplex in vitro amplification of virulenceassociated genes. Applied and Environmental Microbiology, Washington, v. 62, n. 9, p. 3462-3465, Set. 1996.

DILALLO, R.; ALBERTON, O. E. Volatile acids by direct titration. Journal Water Pollution Control Federation, v. 33, n. 4, p. 356356, Abr. 1961. 
DUFFY, G. Verocytoxigenic Escherichia coli in animal faeces, manures and slurries. Journal of Applied Microbiology, v. 94, n. 1, p. 94-103, Abr. 2003. Available from: <http://onlinelibrary. wiley.com/doi/10.1046/j.1365-2672.94.s1.11.x/pdf>. Accessed: Mai. 20, 2017. doi: 10.1046/j.1365-2672.94.s1.11.x.

FREMAUX, B. et al. Long-term survival of Shiga toxin-producing Escherichia coli in cattle effluents and environment: An updated review. Veterinary Microbiology, v. 132, n. 1-2, p. 1-18, Nov. 2008. Available from: <http://www.sciencedirect.com/science/ article/pii/S0378113508001995>. Accessed: Mai. 05, 2017. doi: 10.1016/j.vetmic.2008.05.015

FUKUSHIMA, H. et al. Long-term survival of shiga toxinproducing Escherichia coli O26, O111, and O157 in bovine feces. Applied and Environmental Microbiology, v. 65, n. 11, p. $5177-$ 5181, Nov. 1999

GERBA, C. P.; SMITH JR., J. E. Sources of pathogenic microorganisms and their fate during land application of wastes. Journal of Environmental Quality, v. 34, n. 1, p. 42-48, Jan./ Feb. 2005.

GONÇALVES, V. P.; MARIN, J. M. Fate of non O157 Shiga toxigenic Escherichia coli in composted cattle manure. Arquivo Brasileiro de Medicina Veterinária e Zootecnia, Belo Horizonte, v. 59, n. 4, p. 825-831, 2007. Available from: <http://www.scielo.br/ scielo.php?script $=$ sci arttext\&pid=S0102-09352007000400001 $>$. Accessed: Mai. 25, 2017. doi: 10.1590/S0102-09352007000400001.

GYLES, C. L.; FAIRBROTHER, J. M. Escherichia coli. In: GYLES, C. L.; PRESCOTT, J. F.; SONGER, G.; THOEN, C. O. Pathogenesis of bacterial infections in animals. 4ed. New York: Wiley-Blackwell, 2010. p. 267-308.

HENRY, D. P. et al. Factors affecting the survival of Salmonella and Escherichia coli in anaerobically fermented pig waste. Journal of Applied Microbiology, v. 55, n. 1, p. 89-95, Ago. 1983. Available from: <http://onlinelibrary.wiley.com/ doi/10.1111/j.1365-2672.1983.tb02651.x/full>. Accessed: Mai. 30, 2017. doi: 10.1111/j.1365-2672.1983.tb02651.x.

HIGGINS, M. J. et al. Reactivation and growth of non-culturable indicator bacteria in anaerobically digested biosolids after centrifuge dewatering. Water Research, v. 41, n. 3, p. 665-673, 2007. Available from: <http://www.sciencedirect.com/science/ article/pii/S0043135406005161>. Accessed: Set. 12, 2017. doi: 10.1016/j.watres.2006.09.017

HUTCHISON, M. L. et al. Levels of zoonotic agents in British livestock manures. Letters in Applied Microbiology, v. 39, n. 2, p. 207-214, Ago. 2004. Available from: <http://onlinelibrary.wiley. com/doi/10.1111/j.1472-765X.2004.01564.x/abstract>. Accessed: Mai. 15, 2017. doi: 10.1111/j.1472-765X.2004.01564.x.

IRINO, K. et al. Serotypes and virulence markers of Shiga toxinproducing Escherichia coli (STEC) isolated from dairy cattle in São Paulo State, Brazil. Veterinary Microbiology, v. 105, n. 1, p. 29-36, Jan. 2005. Available from: <http://www.sciencedirect. com/science/article/pii/S0378113504003165>. Accessed: Mai. 18, 2017. doi: 10.1016/j.vetmic.2004.08.007.

ISLAM, M. et al. Persistence of enterohemorrhagic Escherichia coli $\mathrm{O} 157: \mathrm{H} 7$ in soil and on leaf lettuce and parsley grown in fields treated with contaminated manure composts or irrigation water. Journal of Food Protection., v. 67, n. 7, p. 1365-1370, Jul. 2004.
KAPER, J. B. et al. Pathogenic Escherichia coli. Nat. Rev. Microbiol., v. 2, n. 2, p. 123-140, Fev. 2004. Available from: <http:// www.nature.com/nrmicro/journal/v2/n2/full/nrmicro818.html $>$. Accessed: Mai. 18, 2017. doi: 10.1038/nrmicro818.

KUDVA, I. T. et al. Analysis of Escherichia coli O157:H7 survival in ovine or bovine manure and manure slurry. Applied and Environmental Microbiology, v. 64, n. 9, p. 3166-3174, Set. 1998.

KUNTE, D. P. et al. Two-stage anaerobic digestion process for complete inactivation of enteric bacterial pathogens in human night soil. Water Science and Technology., v. 50, n. 6, p. 103108, Set. 2004.

LANG, N. L.; SMITH, S. R. Time and temperature inactivation kinetics of enteric bacteria relevant to sewage sludge treatment processes for agricultural use. Water Research, v. 42, n. 8-9, p. 2229-2241, Abr. 2008. Available from: <http://www.sciencedirect. com/science/article/pii/S0043135407007336>. Accessed: Mai. 21, 2017. doi: 10.1016/j.watres.2007.12.001.

MANYI-LOH, C. E. et al. Inactivation of Selected Bacterial Pathogens in Dairy Cattle Manure by Mesophilic Anaerobic Digestion (Balloon Type Digester). International Journal of Environmental Research Public Health, v. 11, n. 7, p. 7184-7194, Jul. 2014. Available from: <http://www.mdpi.com/1660-4601/11/7/7184>. Accessed: Mai. 05, 2017. doi: 10.3390/ijerph110707184.

MUKHERJEE, A. et al. Soil survival of Escherichia coli O157:H7 acquired by a child from garden soil recently fertilized with cattle manure. Journal of Applied Microbiology, v. 101, n. 2, p. 429436, Ago. 2006. Available from: <http://onlinelibrary.wiley.com/ doi/10.1111/j.1365-2672.2006.02913.x/abstract>. Accessed: Mai. 17, 2017. doi: 10.1111/j.1365-2672.2006.02913.x.

NICHOLSON, F. A. et al. Pathogen survival during livestock manure storage and following land application. Bioresource Technology, v. 96 , n. 2 , p. $135-143$, Jan. 2005. Available from: <http://www. sciencedirect.com/science/article/pii/S0960852404001087>. Accessed: Mai. 05, 2017. doi: 10.1016/j.biortech.2004.02.030.

ORRICO, A. C. A. et al. Anaerobic co-digestion of dairy cattle manure and waste. Journal of the Brazilian Association of Agricultural Engineering, Jaboticabal, v. 36, n. 3, p. 537-545, Mai./Jun. 2016. Available from: <http://www.scielo.br/pdf/eagri/ v36n3/1809-4430-eagri-36-3-0537.pdf $>$. Accessed: Mai. 17, 2017. doi: $10.1590 / 1809-4430$.

ORZI, V. et al. Potential odour emission measurement in organic fraction of municipal solid waste during anaerobic digestion: relationship with process and biological stability parameters. Bioresource Technology, v. 101, n. 19, p. 7330-7337, Out. 2010. Available from: $<$ http://www.sciencedirect.com/science/article/pii/ S0960852410008102>. Accessed: Mai. 21, 2017. doi: 10.1016/j. biortech.2010.04.098

PANDEY, P. K.; SOUPIR, M. L. Escherichia coli inactivation kinetics in anaerobic digestion of dairy manure under moderate, mesophilic and thermophilic temperatures. AMB Express, v. 1, n. 18, p. 1-10, Jul. 2011. Available from: <https://www.ncbi.nlm. nih.gov/pmc/articles/PMC3222320/pdf/2191-0855-1-18.pdf>. Accessed: Mai. 21, 2017. doi: 10.1186/2191-0855-1-18.

SAHLSTRÖM, L. A review of survival of pathogenic bacteria in organic waste used in biogas plants. Bioresource Technology, v. 87 , n. 2, p. 161-166, Abr. 2003. Available from: <http://www. 
sciencedirect.com/science/article/pii/S0960852402001682>. Accessed: Mai. 05, 2017. doi: 10.1016/S0960-8524(02)00168-2.

SAHLSTRÖM, L. et al. A laboratory study of survival of selected microorganisms after heat treatment of biowaste used in biogas plants. Bioresource Technology, v. 99, n. 16, p. 7859-7865, Nov. 2008. Available from: <http://www.sciencedirect.com/science/ article/pii/S0960852407008164>. Accessed: Mai. 05, 2017. doi: 10.1016/j.biortech.2007.09.071

SDA - SECRETARIA DE DEFESA AGROPECUÁRIA - Instrução Normativa $n^{\circ} 27$, de 5 de junho de 2006. "Limites máximos de contaminantes admitidos em fertilizantes orgânicos e condicionadores de solo". Brasília, Brasil, 2006.

SIQUEIRA, A. L.; TIBÚRCIO, J. D. Estatística na área da saúde: conceitos, metodologia, aplicações e prática computacional. 538p. Belo Horizonte: Coopmed, 2011.

STRAUCH, D. Animal hygiene and environmental hygiene. Zentralblatt Fur Bakteriologie Mikrobiologie Und Hygiene, v. 183, n. 2-3, p. 258-273, Dez. 1986.
SUNG, S.; LIU, T. Ammonia inhibition on thermophilic anaerobic digestion. Chemosphere, v. 53, n. 1, p. 43-52, Out. 2003. Available from: $<$ http://www.sciencedirect.com/science/article/pii/ S004565350300434X>. Accessed: Mai. 05, 2017. doi: 10.1016/ S0045-6535(03)00434-X.

SUTTON, C. Accuracy of Plate Counts. Journal Validation Technology, v. 17, n. 3, p. 42-46, 2011.

VAN ELSAS, J. D. et al. Survival of Escherichia coli in the environment: fundamental and public health aspects. ISME Journal, v. 5, n. 2, p. 173-183, Fev. 2011. Available from: <https:// www.ncbi.nlm.nih.gov/pmc/articles/PMC3105702/>. Accessed: Mai. 05, 2017. doi: 10.1038/ismej.2010.80.

VICENTE, H. I. G. et al. Shigatoxin-producing Escherichia coli detected in dairy cattle feces. Arquivos do Instituto Biológico, São Paulo, v. 77, n. 4, p. 567-573, out./dez., 2010.

XAVIER, C. A. N. et al. Anaerobic digestion of dairy cow manure: diet and sugar cane broth addition effect. Archivos de Zootecnia, v. 65 , n. 250 , p. 131-138, Jun. 2016. 